\title{
Silver-Rich Chalcopyrite from the Active Cerro Pabellón Geothermal System, Northern Chile
}

\author{
Martin Reich 1,2,*(D), Nelson Román ${ }^{1,2}$, Fernando Barra ${ }^{1,2}$ and Diego Morata ${ }^{1,2}$ \\ 1 Department of Geology and Andean Geothermal Center of Excellence (CEGA), Facultad de Ciencias \\ Físicas y Matemáticas (FCFM), Universidad de Chile, Plaza Ercilla 803, Santiago 8370450, Chile; \\ nelson.roman.m@gmail.com (N.R.); fbarrapantoja@ing.uchile.cl (F.B.); dmorata@ing.uchile.cl (D.M.) \\ 2 Millennium Nucleus for Metal Tracing Along Subduction (NMTM), Facultad de Ciencias Físicas y \\ Matemáticas (FCFM), Universidad de Chile, Santiago 8370450, Chile \\ * Correspondence: mreich@ing.uchile.cl; Tel.: +56-2-29784986
}

Received: 3 January 2020; Accepted: 22 January 2020; Published: 28 January 2020

\begin{abstract}
Active subaerial geothermal systems are regarded as modern analogues of low- to intermediate-sulfidation epithermal $\mathrm{Au}-\mathrm{Ag}$ deposits, where minor amounts of $\mathrm{Cu}$ are mostly present as chalcopyrite. Although trace element data concerning sulfides are scarce in active geothermal systems at convergent settings, studies in several other environments have demonstrated that chalcopyrite is a relevant host of Ag and other trace elements. Here, we focus on the active Cerro Pabellón geothermal system in the Altiplano of northern Chile, where chalcopyrite-bearing samples were retrieved from a $561 \mathrm{~m}$ drill core that crosscuts the high-enthalpy geothermal reservoir at depth. A combination of EMPA and LA-ICP-MS data shows that chalcopyrite from Cerro Pabellón is silver-rich $(\mathrm{Ag}>1000 \mathrm{ppm})$ and hosts a wide range of trace elements, most notably $\mathrm{Se}, \mathrm{Te}, \mathrm{Zn}$, $\mathrm{Sb}, \mathrm{As}$, and $\mathrm{Ni}$, which can reach $100 \mathrm{~s}$ of ppm. Other elements detected include $\mathrm{Co}, \mathrm{Pb}, \mathrm{Cr}, \mathrm{Ga}, \mathrm{Ge}$, $\mathrm{Sn}, \mathrm{Cd}$, and $\mathrm{Hg}$ but are often present in low concentrations ( $<100 \mathrm{ppm})$, whereas $\mathrm{Au}, \mathrm{Bi}, \mathrm{Tl}$, and In are generally below $1 \mathrm{ppm}$. Chalcopyrite shows a distinct geochemical signature with depth, with significantly higher Ag concentrations in the shallow sample $(494 \mathrm{~m})$ and increasing $\mathrm{Cd}$ and $\mathrm{In}$ contents towards the bottom of the studied drill core $(549 \mathrm{~m})$. These differences in the trace element contents of chalcopyrite are interpreted as related to temperature gradients during the waning stages of boiling at Cerro Pabellón, although further studies are still needed to assess the precise partitioning controls. Our data provide evidence that chalcopyrite may play a relevant role as a scavenger of certain metals and a monitor of fluid changes in hydrothermal systems.
\end{abstract}

Keywords: chalcopyrite; silver; trace elements; geothermal systems; epithermal $\mathrm{Au}-\mathrm{Ag}$; Cerro Pabellón; Chile

\section{Introduction}

Chalcopyrite $\left(\mathrm{CuFeS}_{2}\right)$ is the most important source of copper globally and a primary copper sulfide in a wide variety of magmatic and hydrothermal ore-forming environments. It is a major constituent of mineralization in ore deposits such as magmatic copper-nickel, porphyry copper, iron oxide-copper gold (IOCG), skarn, epithermal gold-silver, volcanogenic massive sulfide (VMS), and sedimentary rock-hosted copper, among others [1-7]. In the past decades, several micro-analytical studies have shown that chalcopyrite can host significant amounts of trace metals, most notably Ag, which is commonly recovered as a by-product of $\mathrm{Cu}$ mining [8-19]. Typically, Ag concentrations in chalcopyrite range between tens and hundreds of parts per million (ppm), although sometimes reaching a few thousand ppm $[16,19]$. Besides $\mathrm{Ag}$, chalcopyrite can host several other elements such as $\mathrm{Mn}, \mathrm{Co}, \mathrm{Zn}, \mathrm{Ga}, \mathrm{Se}, \mathrm{Cd}, \mathrm{In}, \mathrm{Sn}, \mathrm{Sb}, \mathrm{Hg}, \mathrm{Tl}, \mathrm{Pb}$, and $\mathrm{Bi}$, among others [19]. These elements can vary 
from tens to hundreds of ppm in chalcopyrite from several ore deposit types, often exceeding the thousand-ppm level [19].

In modern hydrothermal settings, studies presenting trace element data of chalcopyrite are predominantly restricted to submarine hydrothermal environments, i.e., seafloor massive sulfides and active hydrothermal chimneys. For example, previous studies have reported LA-ICP-MS data showing that chalcopyrite from black smoker vents can host variable amounts of $\mathrm{Zn}, \mathrm{As}, \mathrm{Sb}, \mathrm{Ag}, \mathrm{Pb}, \mathrm{Bi}, \mathrm{Se}, \mathrm{Te}$, $\mathrm{Co}$, and $\mathrm{Ni}$, among other trace elements [12,20-26]. Furthermore, [27] presented micro-analytical data of chalcopyrite retrieved from drill cuttings at the seawater-dominated Reykjanes geothermal system in Iceland. LA-ICP-MS data show that chalcopyrite in Reykjanes is characterized by high contents of $\mathrm{Ag}, \mathrm{Cd}$, Se, and $\mathrm{Zn}$, as well as low As concentrations. For example, the maximum concentrations of Ag measured in chalcopyrite at Reykjanes is $\sim 400 \mathrm{ppm}$, while Se can reach $\sim 470 \mathrm{ppm}$ and $\mathrm{Zn}$ is highly enriched (maximum $0.85 \mathrm{wt} \% \mathrm{Zn}$ ) [27]. Although trace element data of chalcopyrite from active hydrothermal systems are generally scarce, reported concentrations span a remarkably large range, from a few ppm to up to wt \% levels.

In stark contrast to this, no published studies addressing trace element concentrations in chalcopyrite exist for geothermal systems in volcanic arcs at convergent settings. In convergent margins, subaerial geothermal systems are the modern analogues of shallow-level ( $2-3 \mathrm{~km}$ deep) intrusion-centered hydrothermal ore deposits [28]. For instance, epithermal Au-Ag deposits, formed at a depth $<1.5 \mathrm{~km}$ and a temperature $<300{ }^{\circ} \mathrm{C}$, are regarded as the exhumed product of fossil geothermal systems, and host $\sim 6 \%$ of the world's known Au resources and $\sim 17 \%$ of the Ag resources [5,29]. In active geothermal systems, precious $(\mathrm{Au}, \mathrm{Ag})$ and base $(\mathrm{Cu}, \mathrm{Pb}, \mathrm{Zn})$ metal mineralization occurs in the low-to-intermediate sulfidation epithermal environment, forming veins and vugs in hydrothermally altered rocks [30]. Under low-sulfidation conditions, the hydrothermal fluids are reduced, have near-neutral $\mathrm{pH}$, and form low-sulfidation state minerals including pyrite, sphalerite, and chalcopyrite [31,32]. As such, the diversity of trace elements that chalcopyrite may incorporate is potentially relevant to refine geochemical partitioning and ore forming models, considering that no detailed understanding of elemental incorporation within this sulfide is currently available.

Despite the fact that chalcopyrite is a relevant host of $\mathrm{Ag}$ and associated elements, many questions still remain concerning the ranges of concentration of trace metals within this important $\mathrm{Cu}-\mathrm{Fe}$ sulfide, in particular in active geothermal environments and low-sulfidation $\mathrm{Au}-\mathrm{Ag}$ deposits. This study aims to bridge this gap of information by providing new geochemical data of accessory chalcopyrite from the Cerro Pabellón geothermal system in the Altiplano of northern Chile. Here, we used a combination of electron microprobe analysis (EMPA) and laser ablation inductively coupled plasma mass spectrometry (LA-ICP-MS) to characterize the major and trace the element geochemistry of chalcopyrite samples retrieved from a $561 \mathrm{~m}$ drill core that crosscuts the geothermal reservoir at depth. As such, our geochemical data of chalcopyrite provide valuable information for a better understanding elemental partitioning in modern and fossil hydrothermal systems.

\section{Geological Overview}

This study covered samples collected from the Cerro Pabellón geothermal system located $\sim 100 \mathrm{~km}$ north of the city of Calama in northern Chile (Figure 1A). Cerro Pabellón is an active high-enthalpy geothermal system located in the Pampa Apacheta graben and currently hosts the Cerro Pabellón Geothermal Power Plant (48 MWe), the first of its type in South America. A magmatic, high-temperature heat source has been proposed for Cerro Pabellón, based on petrological, geophysical, and geochemical studies [33-39]. The geology of the area is characterized by the Apacheta-Aguilucho Volcanic Complex (AAVC), dacitic domes and rhyolitic, and dacitic and andesitic lava flows (Figure 1B). More detailed descriptions of the geology of the area can be found in [36-39].

The Cerro Pabellón geothermal system is hosted in an andesitic to dacitic volcanic unit, which comprises hydrothermally altered lava flows, volcanic breccias, and tuffs [33,36]. Hydrothermal alteration in the system is profuse, and [36] recognized three main alteration zones, which are, from top 
to bottom, argillic, sub-propylitic, and propylitic. The pervasively altered argillic zone is characterized by smectite, zeolites, hematite, calcite, and silica, while the sub-propylitic alteration zone is dominated by corrensite + chlorite, with albite, quartz, calcite, hematite, stilbite and laumontite. The deeper propylitic alteration zone contains illite + chlorite, with epidote, titanite, albite, adularia, quartz, calcite, pyrite and chalcopyrite [37]. The geothermal system is capped by a 400-m thick low-resistivity layer, which is detected by magnetotelluric methods [33]. For a comprehensive description of Cerro Pabellón, the reader is referred to [36-38], and references therein.
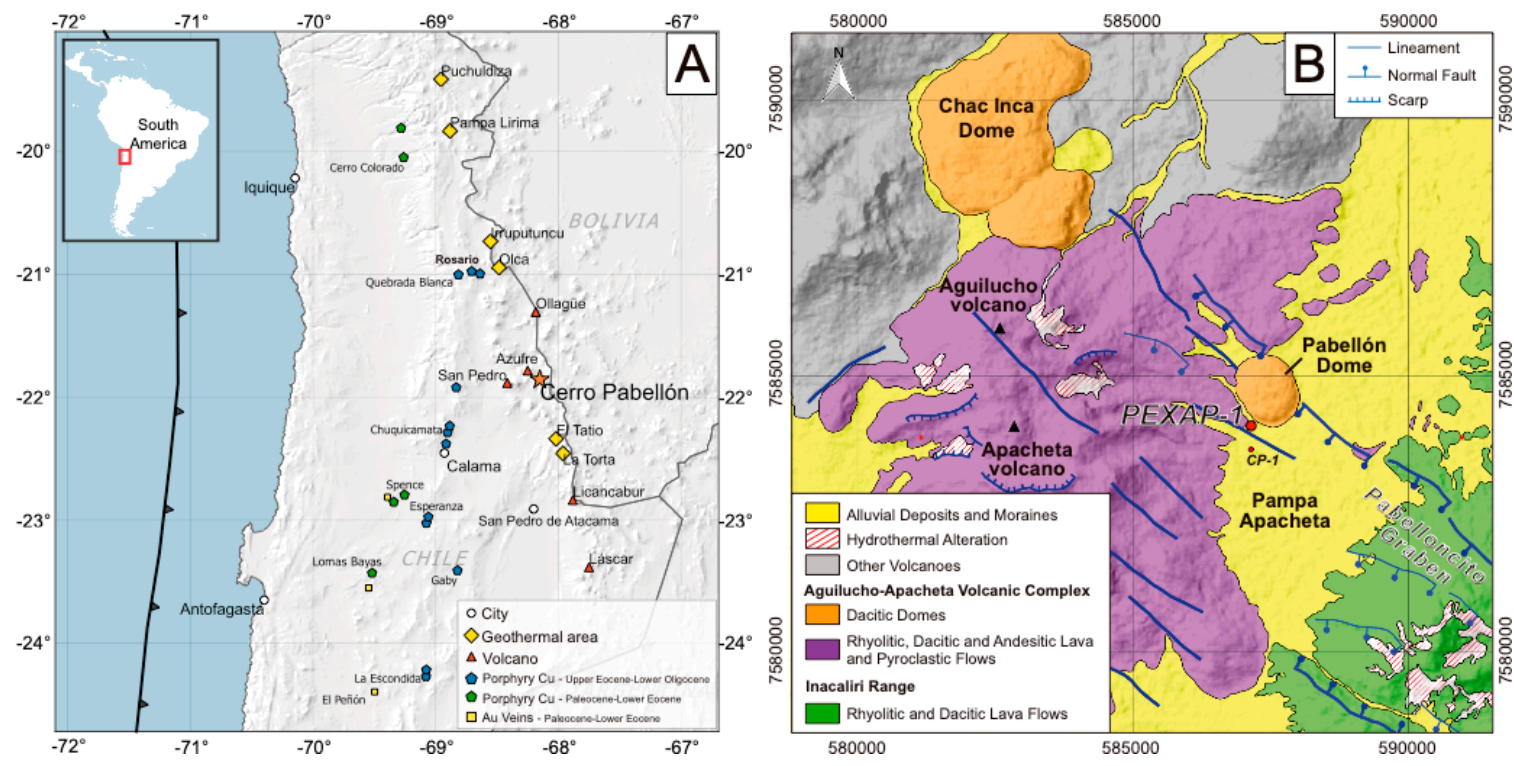

Figure 1. (A) Location of the Cerro Pabellón geothermal system in the Altiplano of northern Chile. (B) A geological map of Cerro Pabellón showing the location of the PEXAP-1 drill hole (red circle). Figures modified from [36,37].

\section{Samples and Methods}

Four representative chalcopyrite-bearing core samples were obtained from a sub-vertical $561 \mathrm{~m}$ drill hole penetrating the geothermal reservoir (drill core PEXAP-1; see [36,37]) (Figure 1B). The four chalcopyrite-bearing samples were retrieved from the last 55 meters of the drill core (494 m to $549 \mathrm{~m}$ ), which intersects the propylitic zone where sulfides are abundant [36,37]. From top to bottom, the four samples are labeled BA-20 (494 m), BA-30 (509 m), BA-34 (520 m), and BA-48 (549 m).

All samples were studied using polarized light and scanning electron microscopy at the Andean Geothermal Centre of Excellence (CEGA). The FEI Quanta 250 SEM at CEGA is equipped with secondary electron (SE), energy-dispersive X-ray spectrometry (EDS) and backscattered electron (BSE) detectors. BSE images were obtained using an accelerating voltage of $15 \mathrm{kV}$, a filament current of 80 $\mu \mathrm{A}$, a beam intensity of $1 \mathrm{nA}$, a spot size of $1-3 \mu \mathrm{m}$, and a working distance of $10 \mathrm{~mm}$.

Major, minor, and trace element concentrations in chalcopyrite were determined using a combination of EMPA and LA-ICP-MS. EMPA determinations were carried out at the Lunar and Planetary Laboratory, University of Arizona, Tucson, using a Cameca SX-100 microprobe equipped with five wavelength-dispersive spectrometers. The counting times were as follows: $20 \mathrm{~s}$ for $\mathrm{Fe} \mathrm{K} \alpha$, Co $\mathrm{K} \alpha, \mathrm{Ni} \mathrm{K} \alpha, \mathrm{Cu} \mathrm{K} \alpha, \mathrm{Zn} \mathrm{K} \alpha, \mathrm{Au} \mathrm{M} \alpha$, and Bi M $\beta$; 30 s for S K $\alpha, \operatorname{Ag} \mathrm{L} \alpha$, Sb L $\alpha$, and Te L $\alpha$; $40 \mathrm{~s}$ for $\mathrm{Pb}$ $\mathrm{M} \alpha$; and $50 \mathrm{~s}$ for As $\mathrm{L} \alpha$ and Se $\mathrm{L} \alpha$. Natural and synthetic metals, sulfides, arsenides, tellurides and selenides were used as standards. For most analyzed elements, mean detection limits varied from 0.02 to $0.05 \mathrm{wt} \%$.

LA-ICP-MS analyses were carried out using a $193 \mathrm{~nm}$ ArF excimer laser (Teledyne-Photon Machines Analyte 193) coupled to a quadrupole ICP-MS (Thermo Fisher Scientific iCAP Q) at the CEGA Mass Spectrometry Laboratory, Department of Geology, Universidad de Chile. The following 
isotopes were monitored: ${ }^{34} \mathrm{~S},{ }^{51} \mathrm{~V},{ }^{52} \mathrm{Cr},{ }^{53} \mathrm{Cr},{ }^{55} \mathrm{Mn},{ }^{57} \mathrm{Fe},{ }^{59} \mathrm{Co},{ }^{60} \mathrm{Ni},{ }^{63} \mathrm{Cu},{ }^{65} \mathrm{Cu},{ }^{66} \mathrm{Zn},{ }^{69} \mathrm{Ga},{ }^{72} \mathrm{Ge}$, ${ }^{73} \mathrm{Ge},{ }^{75} \mathrm{As},{ }^{77} \mathrm{Se},{ }^{82} \mathrm{Se},{ }^{95} \mathrm{Mo},{ }^{97} \mathrm{Mo},{ }^{107} \mathrm{Ag},{ }^{109} \mathrm{Ag},{ }^{111} \mathrm{Cd},{ }^{115} \mathrm{In},{ }^{118} \mathrm{Sn},{ }^{120} \mathrm{Sn},{ }^{121} \mathrm{Sb},{ }^{123} \mathrm{Sb},{ }^{125} \mathrm{Te},{ }^{182} \mathrm{~W}$, ${ }^{197} \mathrm{Au},{ }^{202} \mathrm{Hg},{ }^{205} \mathrm{Tl},{ }^{206} \mathrm{~Pb},{ }^{207} \mathrm{~Pb},{ }^{208} \mathrm{~Pb}$, and ${ }^{209} \mathrm{Bi}$. Analyses were performed following the protocol described by [37]. Before analysis, the ICP-MS was tuned while ablating a NIST SRM 610 glass to ensure acceptable levels of plasma robustness $\left({ }^{238} \mathrm{U}^{+} / 232 \mathrm{Th}^{+}\right.$between $\left.0.95-1.05\right)$, oxide production $\left(\mathrm{ThO}^{+} / \mathrm{Th}^{+}\right.$ $<0.5 \%)$, and double-charged production $\left({ }^{22} \mathrm{M}^{+} /{ }^{44} \mathrm{Ca}^{++}<0.01 \%\right)$. The MASS-1 reference material (pressed synthetic sulfide) was used as the primary standard, and the Fe concentration obtained by EMPA was used as the internal standard. For quality control, the GSE-1G glass reference material was employed as a secondary standard. Ablation was carried out using a laser pulse frequency of $4 \mathrm{~Hz}$, an energy density of $\sim 1.5 \mathrm{~J} / \mathrm{cm}^{2}$, and a spot size of $30 \mu \mathrm{m}$. Helium was used as carrier gas. Each spot was ablated for $30 \mathrm{~s}$ following $30 \mathrm{~s}$ of gas background collection. A dwell time of $10 \mathrm{~ms}$ was used for all elements, except for $\mathrm{Ag}, \mathrm{Cd}, \mathrm{In}, \mathrm{Sn}, \mathrm{Te}, \mathrm{Au}$, and $\mathrm{Bi}$, for which $30 \mathrm{~ms}$ were used. Iolite ${ }^{\mathrm{TM}}$ v. 2.5 [40] was used for data integration and reduction. In order to avoid analytical artifacts, caution was taken in the interpretation of irregular signal profiles attributed to mineral inclusions (spiky profiles) or unstable signals produced when ablating thin mineral grains or grain rims [37].

\section{Results}

\subsection{Micro-Textural Observations}

At Cerro Pabellón, chalcopyrite is late in the sulfide paragenesis, as described by [37]. In the studied samples, chalcopyrite is observed in amygdales and in veinlets and is also disseminated within the volcanic host rocks. Chalcopyrite is mainly associated with late calcite, quartz, adularia, galena, acanthite, and pyrite, precipitating within open spaces after pyrite formation. Figure 2A-D shows representative BSE images of the studied samples. Although chalcopyrite is volumetrically less abundant than pyrite, it is present in all samples forming euhedral to subhedral grains that vary from a few tens to a few hundreds of $\mu \mathrm{m}$. No significant textural variations were observed as a function of depth. In general, chalcopyrite shows pristine surfaces with no visible mineral inclusions (Figure 2A-C). However, some chalcopyrite grains present micrometer- to submicrometer-sized Ag-bearing inclusions, and also a few larger Cu-S-Sb-Ag-bearing inclusions (Figure 2D).

\subsection{EMPA and LA-ICP-MS Data}

EMPA and LA-ICP-MS data are reported in Tables S1 and S2, respectively. The summary statistics of trace element concentrations are presented as a boxplot in Figure 3. Only inclusion-free LA-ICP-MS analyses were included in the boxplot (see data in Table S2).

All major elements measured by EMPA $(\mathrm{Cu}, \mathrm{Fe}$ and $\mathrm{S})$ show homogenous values and low dispersion (Table S1). Copper concentrations of chalcopyrite range from 33.50 to $35.00 \mathrm{wt} \%$, with an average concentration of $34.09 \mathrm{wt} \%$. Iron and sulfur, on the other hand, vary between $29.38-31.22 \mathrm{wt} \%$ (average $30.57 \mathrm{wt} \%$ ) and 34.12-35.33 wt \% (average $34.82 \mathrm{wt} \%$ ), respectively, thus representing a near-stoichiometric chalcopyrite [41].

The EMPA data reveal that chalcopyrite from Cerro Pabellón is enriched in Ag, ranging from 0.03 to $0.31 \mathrm{wt} \%$ (Figure 3). Silver was detected in most analytical spots and has an average concentration of $0.15 \mathrm{wt} \%$. All other analyzed elements were detected only sporadically by EMPA due to the high detection limits of the technique ( $\sim 0.02-0.05 \mathrm{wt} \%$ for most elements). Regardless, their concentration is mostly below $0.1 \mathrm{wt} \%$, e.g., Se (0.02-0.09 wt \%), Sb (0.02-0.23 wt \%), Te (0.04-0.06 wt \%), As (0.02-0.06 wt \%), and $\mathrm{Ni}(0.04-0.05 \mathrm{wt} \%)$. Zinc was detected in only one spot $(0.07 \mathrm{wt} \%)$.

LA-ICP-MS data are in agreement with the electron microprobe results and allow us to obtain geochemical information at the sub-ppm to $100 \mathrm{~s} \mathrm{ppm} \mathrm{level} \mathrm{(Figure} 3$ and Table S2). Besides Ag (average concentration of $1765 \mathrm{ppm}$ ), only Se and Zn display concentrations $>100 \mathrm{ppm}$. Selenium varies from 16 to $740 \mathrm{ppm}$, with an average concentration of $344 \mathrm{ppm}$, whereas $\mathrm{Zn}$ ranges between 274 and 98 ppm (average of 205 ppm). All other elements-Co, Ni, Pb, As, Sb, Bi, Au, Cr, Ga, Ge, Sn, 
$\mathrm{Cd}, \mathrm{Hg}$, In, and $\mathrm{Tl}$-are present in concentrations below $100 \mathrm{ppm}$. Among these, only $\mathrm{Cd}, \mathrm{In}, \mathrm{and} \mathrm{Pb}$ were frequently detected during the LA-ICP-MS analysis. Cadmium concentrations range from 8.4 to $50 \mathrm{ppm}$, the In contents vary between 0.16 and $3.7 \mathrm{ppm}$, and $\mathrm{Pb}$ concentrations range from 0.84 to $25.2 \mathrm{ppm}$. Gold, Bi, and $\mathrm{Tl}$ are up to $\sim 1$ ppm or less.
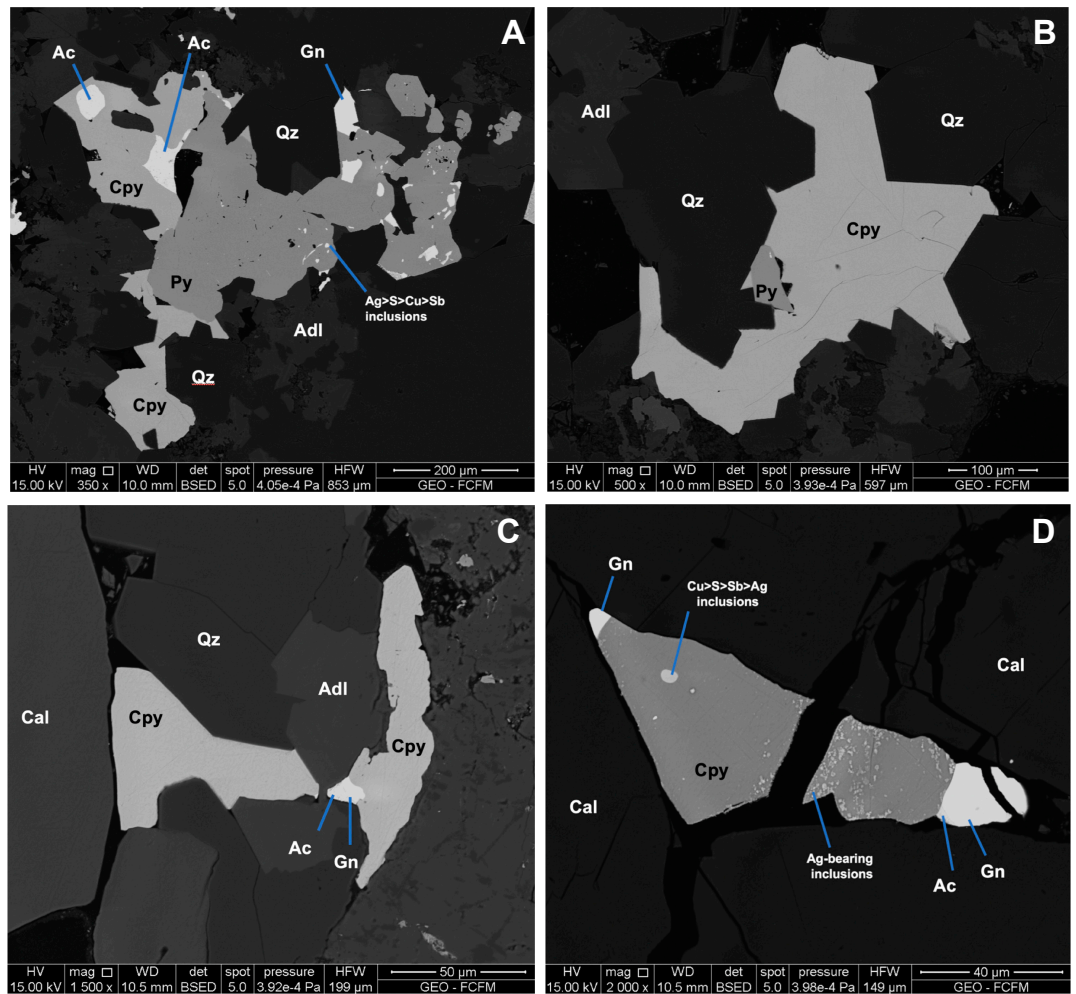

Figure 2. (A-D) show back-scattered electron (BSE) images of chalcopyrite from the Cerro Pabellón geothermal system. Chalcopyrite is euhedral to subhedral and is mostly free of mineral inclusions, although some grains show Ag-bearing micro-inclusions (e.g., (D)) and larger inclusions of Cu-S-Sb-Ag-bearing minerals (e.g., (A) and (D)). Abbreviations: chalcopyrite (Cpy), pyrite (Py), acanthite (Ac), galena (Gn), adularia (Adl), calcite (Cal), quartz (Qz).

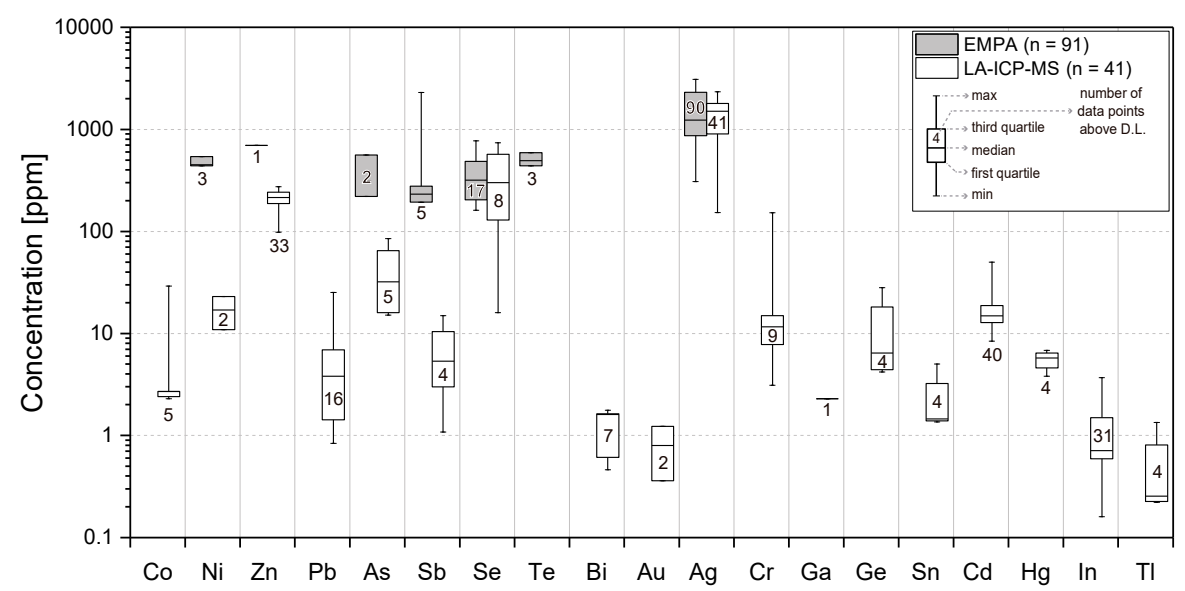

Figure 3. Boxplot of EMPA and LA-ICP-MS data for selected minor and trace elements in chalcopyrite from the Cerro Pabellón geothermal system. Analyses are plotted in parts per million (ppm) on a vertical logarithmic scale. The maximum, median, and minimum concentrations are indicated, as well as the number of analyses above the detection limit for each element (displayed inside or below the boxes). Analyses with "spiky profiles" in Table S2, attributed to inclusions, were not plotted. 


\section{Discussion}

Silver concentrations of chalcopyrite in the Cerro Pabellón geothermal system are high (>1000 ppm) in comparison with several types of hydrothermal ore systems, including porphyry $\mathrm{Cu}$, skarns, VMS, and epithermal Au-Ag deposits [8,9,12,15,16,19]. At Cerro Pabellón, Ag concentrations are at least one order of magnitude higher than all other elements that were frequently detected in the samples by either EMPA or LA-ICP-MS, i.e., Se, $\mathrm{Zn}, \mathrm{Pb}, \mathrm{Cd}$, and In (detected in >15 spot analyses, Figure 3). These data are consistent with [27], which reports trace element data of chalcopyrite from the seawater-dominated Reykjanes geothermal system in Iceland. At Reykjanes, chalcopyrite is characterized by a similar suite of trace elements to those of Cerro Pabellón, among which Ag, $\mathrm{Se}, \mathrm{Zn}, \mathrm{Pb}$, and Cd are the most relevant. However, the concentration range of these elements at Reykjanes and Cerro Pabellón is different, with the exception of Se and $\mathrm{Pb}$, which are similar in both systems (up to $100 \mathrm{~s}$ of ppm and up to $10 \mathrm{~s}$ of ppm, respectively). The average Ag content of chalcopyrite in Cerro Pabellón is one order of magnitude higher ( 1000 ppm) than at Reykjanes ( 100 ppm). Also, In is present in chalcopyrite at Cerro Pabellón (ppb to ppm levels) but is not reported at Reykjanes. In contrast, chalcopyrite from Reykjanes contain higher $\mathrm{Zn}$ and $\mathrm{Cd}$ concentrations than at Cerro Pabellón. Zinc reaches an average content of $\sim 1000$ ppm at Reykjanes, while at Cerro Pabellón its concentration is lower (average $\sim 200 \mathrm{ppm}$ ). Cadmium, on the other hand, is one order of magnitude higher in chalcopyrite from Reykjanes (average $\sim 100 \mathrm{ppm}$ ) than in Cerro Pabellón (average $\sim 10-20$ ppm). Finally, it is relevant to note that $\mathrm{Co}$ and Ni concentrations in chalcopyrite are higher at Reykjanes (up to 1000 ppm and up to $1 \mathrm{wt} \%$ ) than at Cerro Pabellón. In the latter, these two elements were detected in only a few spots. These compositional differences, in particular the low $\mathrm{Co}$ and $\mathrm{Ni}$ concentrations in chalcopyrite studied here, suggest that the hydrothermal system associated with Cerro Pabellón is possibly linked to a relatively more felsic magmatic source [38,39] than at Reykjanes, as proposed by [37] based on the Co/Ni ratios of pyrite. Therefore, and considering that $\mathrm{Co} / \mathrm{Ni}$ ratios in chalcopyrite may be indicative of source components of hydrothermal fluids, further analytical studies in different ore-forming environments should be undertaken to complement the existing data [19,42-44].

At Cerro Pabellón, microanalytical data suggest that Ag is dominantly incorporated in solid solution within chalcopyrite, as most EMPA and LA-ICP-MS analyses show highly homogeneous Ag values (100-1000 ppm range, Table S2 and Figure 3). Furthermore, a detailed inspection of LA-ICP-MS spectra allows us to assess anomalously high Ag concentrations, which usually result from "spiky" LA-ICP-MS profiles (see Table S2, e.g., analysis BA48_10_2, Ag concentration of 9600 ppm, and a few others). These particularly high Ag concentrations can be attributed to the presence of micro- to nano-sized inclusions, based on the presence of ${ }^{107} \mathrm{Ag}$ spikes in the LA-ICP-MS profiles, in contrast to flat ${ }^{107} \mathrm{Ag}$ profiles where structurally bound $\mathrm{Ag}$ is inferred (Figure 4). From the inclusion-free data presented in Figure 3, it is proposed that $\mathrm{Ag}^{+}$was incorporated into the chalcopyrite structure through several coupled substitutions involving monovalent $\left(\mathrm{Cu}^{+}\right)$, bivalent $\left(\mathrm{Zn}^{2+}, \mathrm{Cd}^{2+}, \mathrm{Pb}^{2+}\right)$, trivalent $\left(\mathrm{Fe}^{3+}\right.$, $\left.\mathrm{In}^{3+}, \mathrm{Sb}^{3+}\right)$, and/or tetravalent $\left(\mathrm{Se}^{4+}, \mathrm{Bi}^{4+}, \mathrm{Ge}^{4+}\right)$ ions, as proposed by [45].

Further information on trace element speciation in chalcopyrite can be obtained by inspecting the LA-ICP-MS dataset as a function of depth, where differences in trace element concentrations are noteworthy. Figure 5 shows bivariate plots for selected elements in chalcopyrite from Cerro Pabellón for each analyzed sample. Copper and Ag configure a positive trend only in the shallowest sample (BA-20), while the data points in samples BA-30, BA-40, and BA-48 show a scattered pattern (Figure 5A). The correspondence between $\mathrm{Cu}$ and $\mathrm{Ag}$ in sample BA-20 suggests that both elements are structurally related [45], in agreement with the fact that almost all analyses of this sample are inclusion-free. In contrast, it is likely that Ag in chalcopyrite from the three other samples (i.e., BA-30, BA-40, and BA-48) is contained both in solid solution and also forming Ag-bearing micro- to nano-sized inclusions, as suggested by the relative abundance of analyses with spiky LA-ICP-MS profiles in the deeper samples (e.g., BA-48, Figure 4B). Finally, Zn shows a positive trend with Ag for all samples, suggesting that these two elements are also correlated (Figure 5B). Cd and In do not show any clear correspondence 
with Ag, although the data indicate that higher concentrations of $\mathrm{Cd}$ and $\mathrm{In}$ are generally correlated with lower Ag concentrations.
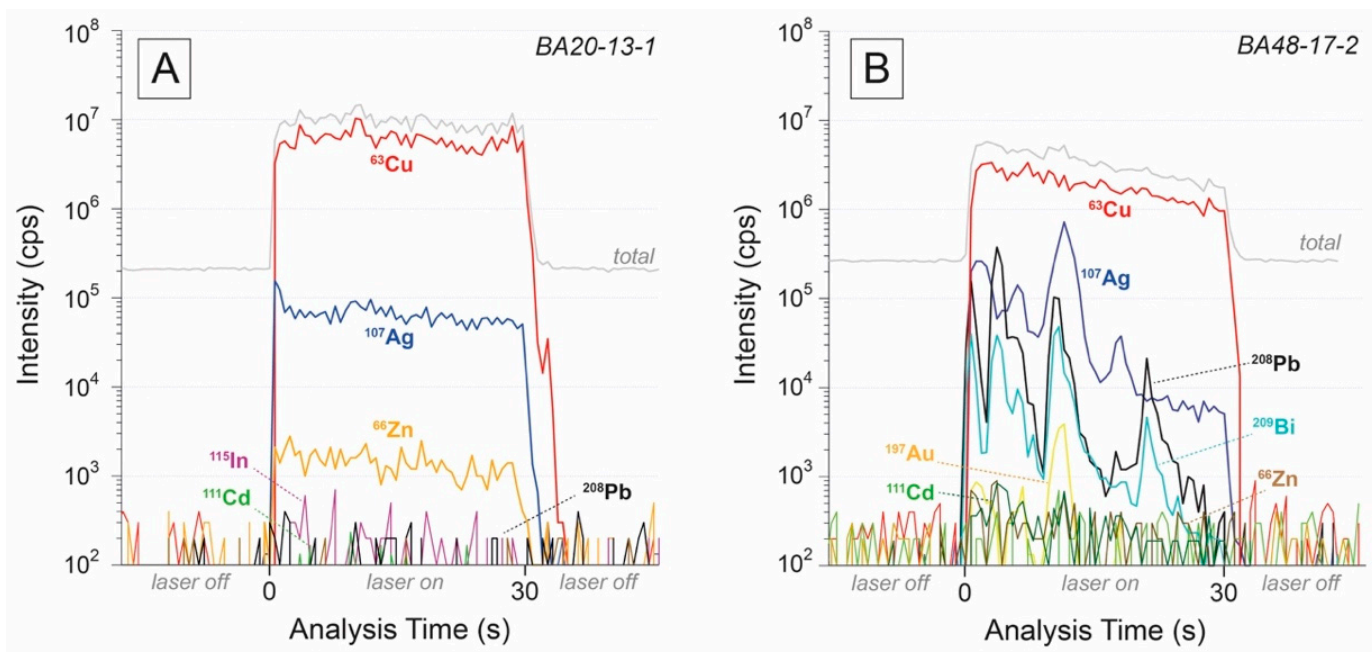

Figure 4. Time (s) vs. intensity (cps) laser ablation inductively coupled plasma mass spectrometry (LA-ICP-MS) depth-concentration profiles of selected isotopes in chalcopyrite from Cerro Pabellón. The ${ }^{107} \mathrm{Ag}$ spectrum in (A) shows a flat profile, suggesting Ag incorporation into solid solution in chalcopyrite (or as nanoparticles not resolved in the LA-ICP-MS profiles). In contrast, the spiky ${ }^{107} \mathrm{Ag}$ signals in (B) are indicative of Ag being present as micro-inclusions in chalcopyrite.
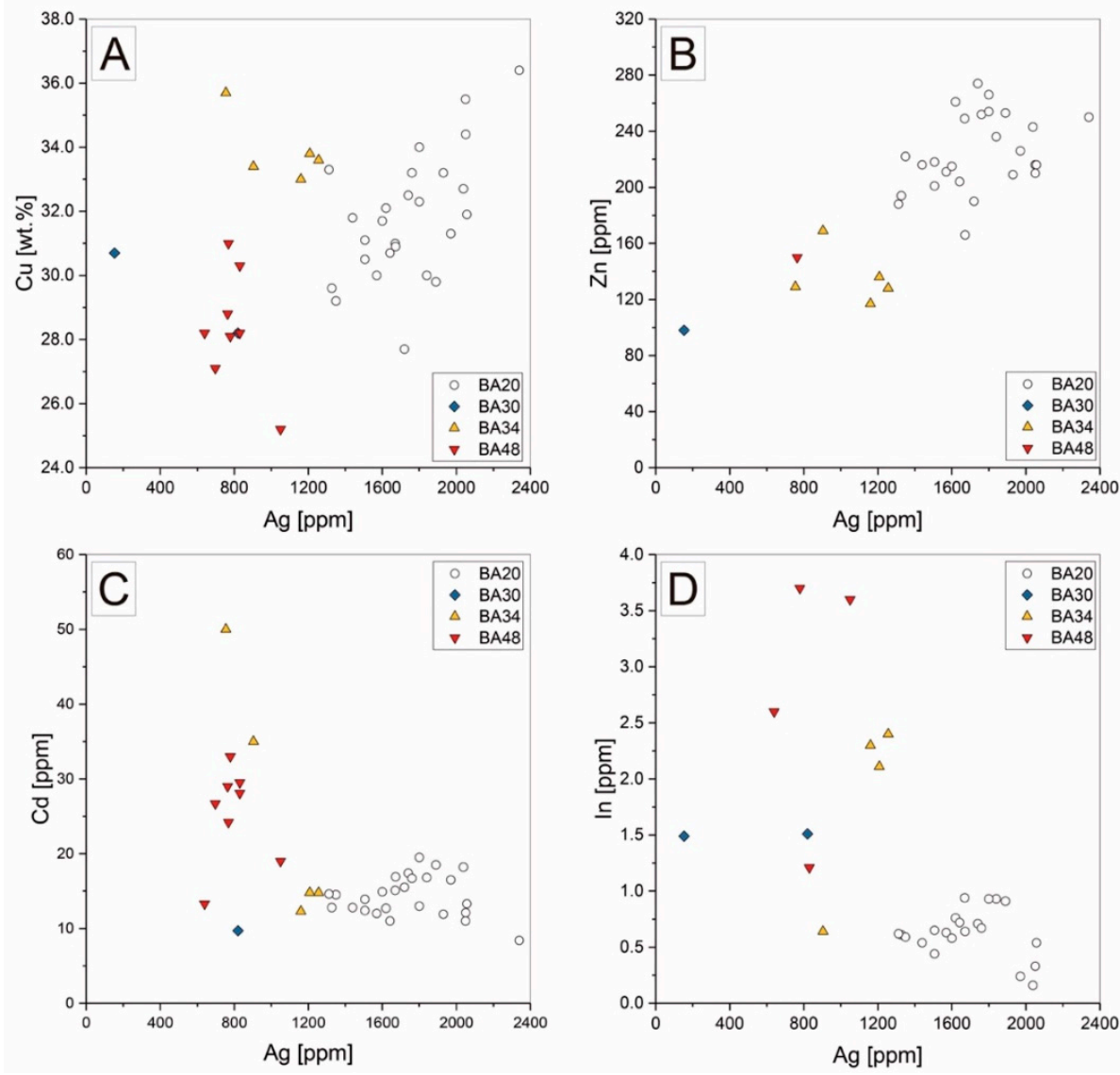

Figure 5. Bivariate plots showing $\mathrm{Cu}-\mathrm{Ag}(\mathbf{A}), \mathrm{Zn}-\mathrm{Ag}(\mathbf{B}), \mathrm{Cd}-\mathrm{Ag}(\mathbf{C})$, and $\mathrm{In}-\mathrm{Ag}(\mathbf{D})$ trends for chalcopyrite from the Cerro Pabellón geothermal system. Samples BA-20 and BA-48 are the shallowest $(494 \mathrm{~m})$ and the deepest $(549 \mathrm{~m})$, respectively, and show distinct variations in trace element concentrations. All plotted data correspond to inclusion-free LA-ICP-MS analyses (see Table S2). 
As mentioned, chalcopyrite from Cerro Pabellón shows distinct variations in $\mathrm{Ag}$, Cd, and In as a function of depth (Figure 5). The shallowest sample, BA-20, is characterized by notoriously higher concentrations of $\mathrm{Ag}(>1300 \mathrm{ppm})$ than the other three deeper samples (<1300 ppm). In contrast, the deepest samples (BA-34 and BA-48) present higher Cd (e.g., up to $50 \mathrm{ppm}$ ) and In (e.g., up to $\sim 3.5$ ppm) than the shallower ones (in BA-20 and BA-30, Cd and In are generally less than 20 ppm and $1.5 \mathrm{ppm}$, respectively). Zinc, on the other hand, generally increases from bottom to top, even though sample BA-30 presents the lowest concentrations.

In [37], the chemical composition, micro-textures, and mineral associations of pyrite at the Cerro Pabellón geothermal system were studied, linking them with specific physico-chemical processes, such as flash boiling and gentle boiling. At Cerro Pabellón, chalcopyrite precipitated late in open spaces and fractures, in association with late pyrite-III (sensu [37]), galena, acanthite, and rhombic calcite. The close association of pyrite-III with the late base metal sulfide mineralization stage suggests that chalcopyrite was formed during the waning stages of the boiling in the studied zone before its complete cessation [37]. Therefore, it is likely that the differences in the trace element composition of chalcopyrite reported here were the result of physico-chemical changes during the late evolution of the Cerro Pabellón geothermal system. The concentration of dissolved $\mathrm{Cu}$ in the hydrothermal fluid, as controlled by the solubility of chalcopyrite, would have significantly decreased as the deep fluid ascended throughout the geothermal reservoir and cooled to $<300{ }^{\circ} \mathrm{C}$, at the top of the propylitic zone [36,37]. Under such conditions, degassing and/or mixing with cooler (meteoric?) fluids would have resulted in the precipitation of Ag-rich chalcopyrite + pyrite \pm galena-acanthite. The specific factors leading to higher Ag concentrations in chalcopyrite at the top of the profile (sample BA-20) need to be further assessed. It is likely that the fluid ascent and cooling/mixing resulted in increased chalcopyrite precipitation on top, below the clay-cap seal. Under these conditions, Ag partitioning into chalcopyrite was probably enhanced, leading to higher Ag concentrations in the shallower sample.

One aspect that needs further attention relates to the effect of co-crystallizing phases that compete for Ag incorporation, for example, sphalerite and galena. In [18], it is shown that chalcopyrite is typically a poor trace element carrier when compared to $\mathrm{Pb}-\mathrm{Zn}$ sulfides. According to [18], chalcopyrite only contains significant concentrations of trace elements in the absence of sphalerite and galena. At Cerro Pabellón, chalcopyrite is mostly related to (late) pyrite-III, which does not contain major amounts of Ag (less than 10 ppm, [37]). Moreover, chalcopyrite is associated with only minor galena and acanthite (Figure 2). Therefore, it is possible that, in a relative absence of other competing base metal sulfides, chalcopyrite was able to concentrate relevant amounts of Ag at Cerro Pabellón. More detailed studies assessing the trace element concentrations of chalcopyrite-bearing assemblages are needed to assess the effect of co-crystallizing phases on elemental partitioning. This factor, along with the potential role of assisting elements [46-49] and/or crystallographic selectivity effects [50,51], should be evaluated in future studies and assessed in detail to better understand Ag uptake by chalcopyrite.

\section{Final Remarks}

EMPA and LA-ICP-MS data reveal that chalcopyrite from the active Cerro Pabellón geothermal system hosts a wide range of trace elements, most notably Ag with >1000 ppm, while Se, Te, Zn, Sb, As, and $\mathrm{Ni}$ can reach 100 s of ppm. Other elements, such as $\mathrm{Co}, \mathrm{Pb}, \mathrm{Cr}, \mathrm{Ga}, \mathrm{Ge}, \mathrm{Sn}, \mathrm{Cd}$, and $\mathrm{Hg}$ are often present in concentrations lower than 100 ppm. Au, Bi, Tl, and In are generally below 1 ppm.

This dataset provides new information about trace element partitioning into chalcopyrite in an active subaerial geothermal system. The microanalytical data reported here allow us to distinguish a distinct geochemical signature of chalcopyrite with depth, with increasing Ag concentrations towards the top of the propylitic zone (immediately below the clay cap seal) and increasing Cd and In contents towards the bottom of the studied drill core. Since the Cerro Pabellón system can be considered a modern analogue of epithermal Au-Ag deposits, these results should motivate further investigations aimed at exploring the potential use of chalcopyrite geochemistry to monitor compositional changes of hydrothermal fluids and its relation to physico-chemical processes, including phase separation. 
In the relative absence of experimental studies documenting elemental partitioning and solubility data for chalcopyrite, the reported dataset provides evidence of selective trace-element enrichment of chalcopyrite, in particular Ag. More detailed studies are needed to constrain the mineralogical site of Ag and associated elements in chalcopyrite and to assess their solid solubility limits under temperature, pressure, and oxygen/sulfur fugacity relevant to hydrothermal systems. Such studies should also assess the potential crystallographic controls on elemental partitioning in chalcopyrite, which remain largely unconstrained.

Supplementary Materials: The following are available online at http://www.mdpi.com/2075-163X/10/2/113/s1, Table S1: Electron microprobe analyses (EMPA) of chalcopyrite from the Cerro Pabellón geothermal system, Chile ( $n=101$, b.d. = below detection limit), Table S2: Chalcopyrite LA-ICP-MS compositional data from the Cerro Pabellón geothermal system, Chile ( $n=54$, b.d. = below detection limit).

Author Contributions: N.R. carried out the drill core sampling, performed EMP and LA-ICP-MS analyses, and reduced the micro-analytical data. M.R. and N.R. wrote and organized the paper. All authors (M.R., N.R., F.B. and D.M.) discussed the results and evaluated the data. All authors have read and agreed to the published version of the manuscript.

Funding: This study work was funded by the Andean Geothermal Center of Excellence (CEGA), FONDAP project \#15090013, and the Iniciativa Científica Milenio grant "Millennium Nucleus for Metal Tracing Along Subduction". Additional funding was provided by CONICYT-FONDEQUIP instrumentation grant EQM120098. N.R. was supported by a M.Sc. scholarship funded by CONICYT PFCHA/Magíster Nacional/2017 (\#22170335).

Acknowledgments: We thank Mathieu Leisen and Rurik Romero for their help during LA-ICP-MS analyses. Kenneth Domanik and Victor Valencia are acknowledged for their help with electron microprobe analyses at the University of Arizona in Tucson. We thank the ENEL Green Power and their geology team for logistical support, and for providing access to the geothermal project and drill core sampling.

Conflicts of Interest: The authors declare no conflict of interest.

\section{References}

1. Barnes, S.J.; Lightfoot, P.C. Formation of magmatic nickel-sulfide ore deposits and processes affecting their copper and platinum-group element contents. In Economic Geology 100th Anniversary; Hedenquist, J.W., Thompson, J.F.H., Goldfarb, R.J., Richards, J.P., Eds.; Society of Economic Geologists, Inc.: Littleton, CO, USA, 2005; pp. 179-213.

2. Sillitoe, R.H. Porphyry copper systems. Econ. Geol. 2010, 105, 3-41. [CrossRef]

3. Barton, M.D. Iron oxide(-Cu-Au-REE-P-Ag-U-Co) systems. Treatise Geochem. 2014, 13, 515-541.

4. Meinert, L.D.; Dipple, G.M.; Nicolescu, S. World Skarn Deposits. In Economic Geology 100th Anniversary; Hedenquist, J.W., Thompson, J.F.H., Goldfarb, R.J., Richards, J.P., Eds.; Society of Economic Geologists, Inc.: Littleton, CO, USA, 2005; pp. 299-336.

5. Simmons, S.F.; White, N.C.; John, D.A. Geological characteristics of epithermal precious and base metal deposits. In Economic Geology 100th Anniversary; Hedenquist, J.W., Thompson, J.F.H., Goldfarb, R.J., Richards, J.P., Eds.; Society of Economic Geologists, Inc.: Littleton, CO, USA, 2005; pp. 485-522.

6. Galley, A.G.; Hannington, M.D.; Jonasson, I.R. Volcanogenic massive sulphide deposits. In Mineral Deposits of Canada: A Synthesis of Major Deposit-Types, District Metallogeny, the Evolution of Geological Provinces, and Exploration Methods; Goodfellow, W.D., Ed.; Geological Association of Canada: St. John's, NL, Canada, 2007; pp. 141-161.

7. Hitzman, M.W.; Selley, D.; Bull, S. Formation of sedimentary rock-hosted stratiform copper deposits through earth history. Econ Geol. 2010, 105, 627-639. [CrossRef]

8. Harris, D.C.; Cabri, L.J.; Nobiling, R. Silver-bearing chalcopyrite, a principal source of silver in the Izok Lake massive-sulfide deposit; confirmation by electron- and proton-microprobe analyses. Can. Mineral. 1984, 22, 493-498.

9. Cabri, L.J.; Campbell, J.L.; Laflamme, J.H.G.; Leigh, R.G.; Maxwell, J.A.; Scott, J.D. Proton-micro- probe analysis of trace elements in sulfides from some massive-sulfide deposits. Can. Mineral. 1985, 23, 133-148. 
10. Larocque, A.C.L.; Jackman, J.A.; Cabri, L.J.; Hodgson, C.J. Calibration of the ion microprobe for the determination of silver in pyrite and chalcopyrite from the Mobrun VMS deposit, Rouyn-Noranda, Quebec. Can. Mineral. 1995, 33, 361-372.

11. Huston, D.L.; Sie, S.H.; Suter, G.F.; Cooke, D.R.; Both, R.A. Trace elements in sulfide minerals from eastern Australian volcanic-hosted massive sulfide deposits: Part I. Proton microprobe analyses of pyrite, chalcopyrite, and sphalerite, and Part II. Selenium levels in pyrite: comparison with $\delta^{34} \mathrm{~S}$ values and implications for the source of sulfur in volcanogenic hydrothermal systems. Econ. Geol. 1995, 90, 1167-1196.

12. Butler, I.B.; Nesbitt, R.W. Trace element distributions in the chalcopyrite wall of a black smoker chimney: Insights from laser ablation inductively coupled plasma mass spectrometry (LA-ICP-MS). Earth Planet. Sci. Lett. 1999, 167, 335-345. [CrossRef]

13. Ayres, R.U.; Ayres, L.W.; Råde, I. The Life Cycle of Copper; its Co-Products and Byproducts. In Eco-Efficiency in Industry and Science; Kluwer Academic Publishers: Dordrecht, The Netherlands, 2013; 199p.

14. Arif, J.; Baker, T. Gold paragenesis and chemistry at Batu Hijau, Indonesia: Implications for gold-rich porphyry copper deposits. Miner. Deposita 2004, 39, 523-535. [CrossRef]

15. Cook, N.J.; Ciobanu, C.L.; Danyushevsky, L.V.; Gilbert, S. Minor and trace elements in bornite and associated $\mathrm{Cu}-(\mathrm{Fe})$ sulfides: A LA-ICP-MS study. Geochim. Cosmochim. Acta 2011, 75, 6473-6496. [CrossRef]

16. Reich, M.; Palacios, C.; Barra, F.; Chryssoulis, S. "Invisible" silver in chalcopyrite and bornite from the Mantos Blancos copper deposit. Eur. J. Mineral. 2013, 25, 453-460. [CrossRef]

17. Cioaca, M.E.; Munteanu, M.; Qi, L.; Costin, G. Trace element concentrations in porphyry copper deposits from Metaliferi Mountains, Romania: A reconnaissance study. Ore Geol. Rev. 2014, 63, 22-39. [CrossRef]

18. George, L.L.; Cook, N.J.; Ciobanu, C.L. Partitioning of trace elements in co-crystallized sphalerite-galenachalcopyrite hydrothermal ores. Ore Geol. Rev. 2016, 77, 97-116. [CrossRef]

19. George, L.L.; Cook, N.J.; Crowe, B.B.P.; Ciobanu, C.L. Trace elements in hydrothermal chalcopyrite. Mineral. Mag. 2018, 82, 59-88. [CrossRef]

20. Wohlgemuth-Ueberwasser, C.C.; Viljoen, F.; Petersen, S.; Vorster, C. Distribution and solubility limits of trace elements in hydrothermal black smoker sulfides: An in situ LA-ICP-MS study. Geochim. Cosmochim. Acta 2015, 159, 16-41. [CrossRef]

21. Maslennikov, V.V.; Maslennikova, S.P.; Large, R.R.; Danyushevsky, L.V.; Herrington, R.J.; Ayupova, N.R.; Zaykov, V.V.; Lein, A.Y.; Tseluyko, A.S.; Melekestseva, I.Y.; et al. Chimneys in Paleozoic massive sulfide mounds of the Urals VMS deposits: mineral and trace element comparison with modern black, grey, white and clear smokers. Ore Geol. Rev. 2017, 85, 64-106. [CrossRef]

22. Melekestseva, I.Y.; Maslennikov, V.V.; Tret'Yakov, G.A.; Nimis, P.; Beltenev, V.E.; Rozhdestvenskaya, I.I.; Maslennikova, S.P.; Belogub, E.V.; Danyushevsky, L.V.; Large, R.R.; et al. Gold- and Silver-Rich Massive Sulfides from the Semenov-2 Hydrothermal Field, $13^{\circ} 31.13^{\prime} \mathrm{N}$, Mid-Atlantic Ridge: A Case of Magmatic Contribution? Econ. Geol. 2017, 112, 741-773. [CrossRef]

23. Alexandre, P.; Heine, T.; Fayek, M.; Potter, E.; Sharpe, R. Ore mineralogy of the Chisel Lake Zn-Cu-Ag (+Au) VMS deposit in the Flin Flon—Snow Lake Domain, Manitoba, Canada. Can. Mineral. 2019, 57, 925-945. [CrossRef]

24. Shalaby, I.M.; Stumpfl, E.; Helmy, H.M.; El Mahallawi, M.M.; Kamel, O.A. Silver and silver-bearing minerals at the Um Samiuki volcanogenic massive sulphide deposit, Eastern Desert, Egypt. Miner. Depos. 2004, 39, 608-621. [CrossRef]

25. Yuan, B.; Yang, Y.; Yu, H.; Zhao, Y.; Ding, Q.; Yang, J.; Tang, X. Geochemistry of pyrite and chalcopyrite from an active black smoker in $49.6^{\circ}$ E Southwest Indian Ridge. Mar. Geophys. Res. 2018, 39, 441. [CrossRef]

26. Fallon, E.K.; Frische, M.; Petersen, S.; Brooker, R.A.; Scott, T.B. Geological, Mineralogical and Textural Impacts on the Distribution of Environmentally Toxic Trace Elements in Seafloor Massive Sulfide Occurrences. Minerals 2019, 9, 162. [CrossRef]

27. Libbey, R.B.; Williams-Jones, A.E. Relating sulfide mineral zonation and trace element chemistry to subsurface processes in the Reykjanes geothermal system, Iceland. J. Volcanol. Geoth. Res. 2016, 310, 225-241. [CrossRef] 
28. Hedenquist, J.W.; Lowenstern, J.B. The Role of Magmas in the Formation of Hydrothermal Ore Deposits. Nature 1994, 370, 519-527. [CrossRef]

29. Wilkinson, J.J.; Simmons, S.F.; Stoffell, B. How metalliferous brines line Mexican epithermal veins with silver. Sci. Rep. 2013, 3, 2057. [CrossRef]

30. Brown, K.L. Gold deposition from geothermal discharges in New Zealand. Econ. Geol. 1986, 81, 979-983. [CrossRef]

31. Barton, P.B., Jr.; Skinner, B.J. Sulfide mineral stabilities. In Geochemistry of Hydrothermal Ore Deposits; Barnes, H.L., Ed.; Wiley Interscience: New York, NY, USA, 1979; pp. 278-403.

32. White, N.C.; Leake, M.J.; McCaughey, S.N.; Parris, B.W. Epithermal deposits of the southwest Pacific. J. Geochem. Explor. 1995, 54, 87-136. [CrossRef]

33. Urzúa, L.; Powell, T.; Cumming, W.; Dobson, P. Apacheta, a new geothermal prospect in Northern Chile. Geotherm. Resour. Council Trans. 2002, 26, 65-69.

34. Piscaglia, F. The high temperature geothermal field of the Apacheta-Aguilucho Volcanic Complex (northern Chile): Geo-petrographic surface exploration, crustal heat sources and cap-rocks. Plinius 2012, 38, 148-153.

35. Mercado, J.L.; Ahumada, S.; Aguilera, F.; Medina, E.; Renzulli, A. Geological and Structural Evolution of ApachetaAguilucho Volcanic Complex (AAVC), Northern Chile. Actas XII Congreso Geológico Chileno. 2019. Santiago Chile (S7:002). Available online: https://pdfs.semanticscholar.org/738e/e1837bd8c577546e7ec3c048e940ffaf423d. pdf (accessed on 23 January 2020).

36. Maza, S.N.; Collo, G.; Morata, D.; Lizana, C.; Camus, E.; Taussi, M.; Renzulli, A.; Mattioli, M.; Godoy, B.; Alvear, B.; et al. Clay mineral associations in the clay cap from the Cerro Pabellón blind geothermal system, Andean Cordillera, Northern Chile. Clay Miner. 2018, 53, 117-141. [CrossRef]

37. Román, N.; Reich, M.; Leisen, M.; Morata, D.; Barra, F. Geochemical and micro-textural fingerprints of boiling in pyrite. Geochim. Cosmochim. Acta 2019, 246, 60-85. [CrossRef]

38. Taussi, M.; Nisi, B.; Pizarro, M.; Morata, D.; Veloso, E.A.; Volpi, G.; Vaselli, O.; Renzulli, A. Sealing capacity of clay-cap units above the Cerro Pabellón hidden geothermal system (northern Chile) derived by soil $\mathrm{CO}_{2}$ flux and temperature measurements. J. Volcanol. Geoth. Res. 2019, 384, 1-14. [CrossRef]

39. Taussi, M.; Godoy, B.; Piscaglia, F.; Morata, D.; Agostini, S.; Le Roux, P.; Gonzalez-Maurel, O.; Gallmeyer, G.; Menzies, A.; Renzulli, A. The upper crustal magma plumbing system of the Pleistocene Apacheta-Aguilucho Volcanic Complex area (Altiplano-Puna, northern Chile) as inferred from the erupted lavas and their enclaves. J. Volcanol. Geoth. Res. 2019, 373, 179-198. [CrossRef]

40. Paton, C.; Hellstrom, J.; Paul, B.; Woodhead, J.; Hergt, J. Iolite: freeware for the visualisation and processing of mass spectrometric data. J. Anal. At. Spectrom. 2011, 26, 2508-2518. [CrossRef]

41. Bowles, J.F.W.; Howie, R.A.; Vaughan, D.J.; Zussman, J. Non-silicates: Oxides, Hydroxides, and Sulfides. In Rock-Forming Minerals, 2nd ed.; The Geological Society of London: London, UK, 2011; Volume 5A, 920p.

42. Thole, R.H. The geology of the Shamrocke mine, Rhodesia-A stratiform copper deposit. Econ. Geol. 1976, 71, 202-228. [CrossRef]

43. Bajwah, Z.; Seccombe, P.; Offler, R. Trace element distribution, Co:Ni ratios and genesis of the Big Cadia iron-copper deposit, New South Wales, Australia. Miner. Depos. 1987, 22, 292-300. [CrossRef]

44. Wang, Z.; Xu, D.; Zhang, Z.; Zou, F.; Wang, L.; Yu, L.; Hu, M. Mineralogy and trace element geochemistry of the Co-and Cu-bearing sulfides from the Shilu $\mathrm{Fe}-\mathrm{Co}-\mathrm{Cu}$ ore district in Hainan Province of South China. J. Asian Earth Sci. 2015, 113, 980-997. [CrossRef]

45. Belissont, R.; Munoz, M.; Boiron, M.C.; Luais, B.; Mathon, O. Germanium Crystal Chemistry in Cu-Bearing Sulfides from Micro-XRF Mapping and Micro-XANES Spectroscopy. Minerals 2019, 9, 227. [CrossRef]

46. Reich, M.; Kesler, S.E.; Utsunomiya, S.; Palenik, C.S.; Chryssoulis, S.L.; Ewing, R.C. Solubility of gold in arsenian pyrite. Geochim. Cosmochim. Acta 2005, 69, 2781-2796. [CrossRef]

47. Reich, M.; Chryssoulis, S.L.; Deditius, A.; Palacios, C.; Zuniga, A.; Weldt, M.; Alvear, M. “Invisible” silver and gold in supergene digenite (Cu1.8S). Geochim. Cosmochim. Acta 2010, 74, 6157-6173. [CrossRef]

48. Ciobanu, C.L.; Cook, N.J.; Pring, A.; Brugger, J.; Danyushevsky, L.V.; Shimizu, M. "Invisible gold” in bismuth chalco- genides. Geochim. Cosmochim. Acta 2009, 73, 1970-1999. [CrossRef] 
49. Deditius, A.P.; Reich, M.; Kesler, S.E.; Utsunomiya, S.; Chryssoulis, S.L.; Walshe, J.; Ewing, R.C. The coupled geochemistry of $\mathrm{Au}$ and $\mathrm{As}$ in pyrite from hydrothermal ore deposits. Geochim. Cosmochim. Acta 2014, 140, 644-670. [CrossRef]

50. Becker, U.; Rosso, K.M.; Hochella, M.F. The proximity effect on semiconducting mineral surfaces: A new aspect of mineral surface reactivity and surface complexation theory? Geochim. Cosmochim. Acta 2001, 65, 2641-2649. [CrossRef]

51. Chouinard, A.; Paquette, J.; Williams-Jones, A.E. Crystallographic controls on trace-element incorporation in auriferous pyrite from the epithermal high-sulfidation Pascua deposit, Chile-Argentina. Can. Mineral. 2005, 43, 951-963. [CrossRef]

(C) 2020 by the authors. Licensee MDPI, Basel, Switzerland. This article is an open access article distributed under the terms and conditions of the Creative Commons Attribution (CC BY) license (http://creativecommons.org/licenses/by/4.0/). 